- родом, типом і видом. Теоретично обгрунтовано напрямки сучасного приватизаційного процесу та ефективну стратегію реструктуризації.

Визначено передумови здійснення приватизації окремих підприємств залізничного транспорту зі зміною власника шляхом перетворення державної власності в недержавну та роздержавлення другого роду, яке не пов'язане зі зміною типу власності. На підставі досвіду здійснення приватизації було сформульовано принципи, за якими вона здійснюється.

\section{СПИСОК ЛІТЕРАТУРИ}

1. В. Андрефф. Новая корпоративная стратегия/ В. Андрефф, Т. Розбард. - Спб.: Питер Ком. - 2009. - 416 c

2. Антикризисный менеджмент/ М.Фрідмен, Р.Маржолен, Р.Прайк, - М.: Тандемэмос. $-2001 .-368$ с.

3. Дж.Гелбрейт. Основы приватизации и предпосылки. Пер. с англ./ Дж.Гелбрейт, Дж.Робінсон. - М.: «Дело». - 1992. - 702 с.
4. I. Бондар. Особенности нынешнего этапа реформирования/ I. Бондар, В. Беседин //Железнодорожный транспорт, 2002. - № 12. - С. 40-46.

5. Л. Верховодов. Проблемы и предпосылки эффективной реструктуризации предприятий/ Л. Верховодов, П. Кучерявенко// Экономика Украины. - 2000. - № 8. - С. 39-47.

6. Ю. Ехануров. Глобальні трансформації і стратегії розвитку різних форм власності. Монографія/ Ю. Ехануров, 3. Мочерний. - Одеса: НАН України. - 1998. - 416 с.

7. М. Чечетов. Основы приватизации и функционального управления убыточными предприятиями: Учеб.пособие/ М. Чечетов. - Спб.: Изд-во Михайлова В.А. - 1999. - 380 с.

8. Р. Євстигнєєв. Эффективное управление фирмой: современная теория и практика/ Р.Свстигнєєв, П.Буніч, В.Медведєв др. Спб.: Изд. дом «Бизнесс-пресса». - 1999. - 416 с.

УДК 656.224

\title{
ЛОГІСТИЧНИЙ ПІДХІД ДО ВЗАСМОДІЇ МАГІСТРАЛЬНОГО І ПРОМИСЛОВОГО ЗАЛІЗНИЧНОГО ТРАНСПОРТУ
}

\author{
Полякова О.М., к.е.н., доцент (УкрДУЗТ)
}

В статті розглянуто правові, технічні, технологічні та інформачійні аспекти взаємодіі магістрального $і$ промислового залізничного транспорту України,проаналізовано проблеми співпраці виробників $i$ перевізників у рамках транспортно-виробничих систем, доведено необхідність застосування логістичного підходу до розв'язання проблем взаємодії промислових комплексів із залізничним транспортом, визначено доцільність формування інформаційно-логістичного иентру 3 метою забезпечення координації та інтеграції взаємодії магістральних і промислових транспортних систем.

Ключові слова: промисловий залізничний транспорт, махістральний транспорт, логістичний підхід, інформаційно-логістичний центр.

\section{ЛОГИСТИЧЕСКИЙ ПОДХОД К ВЗАИМОДЕЙСТВИЮ МАГИСТРАЛЬНОГО И ПРОМЫШЛЕННОГО ЖЕЛЕЗНОДОРОЖНОГО ТРАНСПОРТА}

\section{Полякова Е.Н., к.э.н., доцент (УкрГУЖТТ)}

В статье рассмотрены правовые, технические, технологические и информационные аспекты взаимодействия магистрального и промышленного железнодорожного транспорта Украинь, проанализированы проблемы сотрудничества производителей и перевозчиков в рамках транспортнопроизводственных систем, доказана необходимость применения логистического подхода к решению проблем взаимодействия промышленных комплексов с железнодорожным транспортом, определена изелесообразность формирования информационно-логистического цеентра с целью обеспечения координации и интеграции взаимодействия магистральных и промышленных транспортных систем.

Ключевые слова: промышленный жселезнодорожсный транспорт, магистральный транспорт, логистический подход, информационно-логистический центр. 


\section{LOGISTICAL APPROACH TO THE MAIN AND INDUSTRIAL INTERACTION RAILWAYS}

\section{Polyakova E.N, Candidate of Economics, associate professor (USU of RT)}

The article deals with the legal, technical, technological and informational aspects of the interaction of main and industrial railway transportation in Ukraine. The factors that determine the broad application of the theory of logistics and supply chain management in the development of logistics systems. The trends that require improvement and development of the methodology of interaction of production and transport. The problems of cooperation of manufacturers and carriers in the framework of transport and production systems. We prove the need for a logistics approach to the problems of interaction of industrial complexes to rail transport, integrated application of best practices and the use of modern scientific methods, involving a wide range of specialists railways, industrial and scientific organizations of the transport industry. Determine whether the formation of information and logistics center. Fnktsionirovanie information and logistics center will ensure the coordination and integration of the participants in the process of transportation, compliance with the most important optimality criteria such as quality, reliability and safety of traffic.

Keywords: industrial railway transport, main transport, logistics approach, information and logistics center.

Постановка проблеми. Критерій ефективності сучасного виробництва багато в чому визначається часткою транспортних, вантажнорозвантажувальних і складських робіт, на які припадає в середньому понад $20 \%$ загальних витрат. За кордоном і в Україні все більше уваги звертається на можливість застосування логістичного підходу в якості всеосяжної стратегії організації виробництва, транспорту, складування і збуту.

В даний час транспортна система України включає більше 7000 під'їзних шляхів загальною протяжністю понад 27 тис. км (для порівняння експлуатаційна довжина магістральних залізничних шляхів становить 21,7 тис. км) [1]. При цьому відомчими та промисловими коліями переміщується в 3-3,5 рази більше вантажів, ніж залізничними магістралями.

Проте у взаємодії магістральних і промислових транспортних систем в даний час існує багато проблем, невирішених належною мірою через невідповідність існуючої технології та технічного оснащення промислового транспорту, а також прийнятої системи організації взаємодії 3 магістральним транспортом, новим ринковим умовам роботи. Логістичний підхід до проблем взаємодії промислових комплексів із залізничним транспортом дозволить поліпшити транспортне обслуговування вантажовласників, підвищити ефективність використання транспортних засобів, прискорити просування вантажів.

Цілком очевидно, що забезпечення ефективної взаємодії промислового і магістрального залізничного транспорту має важливе економічне і соціальне значення, будучи одним 3 істотних факторів привабливості галузі, вимагає комплексного підходу до реалізації та пошуку нових методів управління.

Аналіз останніх досліджень і публікацій. Виділення невирішених частин загальної проблеми. Наукові основи організації транспортного обслуговування підприємств i взаємодії різних видів транспорту розроблені в наукових працях I.M. Аксьонова, А.В. Дмитрієва, В. Г. Галабурди, В. Н. Лівшиця, В. В. Повороженка, Н. К. Сологуба, А. А. Тимошина, М.І. Шмулевича та ін. [6, 11, 15]. Різні аспекти транспортної логістики, теоретичні та прикладні питання розвитку логістичної інфраструктури відображені в роботах закордонних і вітчизняних вчених: М.I. Данька, В.Л. Диканя, Л.Б. Миротіна, І.Л. Назаренко, Т.Г. Сухорукової, А.Н. Рахмангулова, B.I. Сергєєва, А.А. Смєхова, Н.В. Якименко [3-5, 7, $8,11]$.

Аналіз праць даних вчених дозволяє зробити висновок про те, що в сукупності ці роботи представляють собою наукову базу сучасних методів взаємодії різних видів транспорту i організації транспортного обслуговування виробництва. В той же час механізм взаємодії магістрального i промислового залізничного транспорту в частині організаційно-правових, технічних, технологічних аспектів співпраці потребує подальшого дослідження.

Постановка завдання. Метою статті $\epsilon$ аналіз основних проблем взаємодії магістрального залізничного транспорту i залізничного промислового транспорту незагального користування та виявлення напрямків підвищення ефективності взаємовідносин.

Виклад основного матеріалу. Інтеграція виробництва веде до високої взаємної залежності виробничо-транспортного процесу на базі нових відносин. Транспорт, як галузь нематеріального виробництва, здійснює неабиякий вплив на пожвавлення транспортної активності держави, забезпечуючи тим самим іiї економічне зростання. 3 іншого боку, транспорт, виступаючи інфраструктурною галуззю, перебуває в значній 
залежності від промислового виробництва та сільського господарства, оскільки він виступає як споживач продукції, так i основний засіб іiі транспортування [4].

Сьогодні існує, принаймні, три чинники, які визначають широке застосування методів логістики та теорії управління ланцюгами поставок в сфері розвитку логістичних систем:

- глобальна інформатизація транспортних процесів;

- розширення перспектив інтеграції між логістичними партнерами, яка зумовлює відмову від міжвидової конкуренції транспорту на користь логістичної координації зусиль по залученню додаткових вантажопотоків;

- зростання складності організаційноекономічних відносин в транспортно-логістичних системах під впливом глобалізації [6].

Слід зазначити, що транспортна складова виробничої інфраструктури та логістична складова ринкової інфраструктури в певній мірі $\epsilon$ взаємодоповнюючими елементами: наявність розвиненої транспортної системи дозволяє значно підвищити рівень логістичних послуг ринкової інфраструктури. Однак ступінь взаємодоповнення цих структур певною мірою залежить від ступеня доступності логістичного сервісу однаково для виробництва всіх галузей реальних секторів економіки в регіоні [12].

Одним 3 найважливіших елементів логістичної системи $€$ взаємодія транспортного комплексу з вантажовласниками - відправниками та одержувачами вантажів. Основні завдання, що виникають на цій ділянці транспортного комплексу, можна звести до чотирьох видів взаємодії: правового, технічного, технологічного та інформаційного.

Правова взаємодія базується на нормативних правових актах, що регулюють взаємовідносини сторін і покликаних створити умови для їх рівноправного партнерства i взаємовигідного співробітництва.

Технічна взаємодія передбачає створення технічних засобів i погоджений розвиток інфраструктури, що забезпечують комплексну роботу магістрального і промислового транспорту.

Технологічна взаємодія магістрального і промислового транспорту розглядає завдання взаємодії в єдиному технологічному процесі (ЄТП) роботи під'їзних колій i станцій примикання, організацію доставки вантажів за жорсткими нитками графіка, складання графіка подач (прибирань) по під'їзній колії, планування відвантаження продукції 3 урахуванням накопичення поїздів і груп вагонів на станції примикання та ін.

Інформаційна взаємодія вантажовласників i підприємств промислового залізничного транспорту із залізницями забезпечує можливість прогнозування i планування майбутньої роботи, організацію електронного документообігу, прискорення передачі даних та підвищення достовірності інформації [15].

У той же час, координація дій промислового транспорту як у його розвитку, так $\mathrm{i}$ у взаємодії 3 власниками і залізничним транспортом загального користування не носить системного характеру. В процесі формування ринку транспортних послуг в Україні намітився ряд тенденцій, що вимагають вдосконалення i розвитку методології взаємодії виробництва i транспорту.

Основною тенденцією ринку пропозицій транспортних послуг $є$ збільшення числа перевізників i, як наслідок, зменшення числа транспортних засобів, що перебувають у власності або орендуються одним перевізником. Загальною проблемою для видів транспорту стає збільшення частки порожнього пробігу транспортних засобів. 3 іншого боку, на ринку споживання транспортних послуг спостерігається зростання потреби підприємств у своєчасних перевезеннях, а також прагнення споживачів транспортної продукції до скорочення своїх транспортно-складських витрат шляхом зменшення розміру транспортної партії. Обидві розглянуті тенденції в сукупності призводять до ускладнення структури вантажопотока.

В умовах організаційної роз'єднаності систем магістрального і промислового транспорту виявлені тенденції призводять до збільшення втрат на замикаючих ділянках транспортного обслуговування виробництва. Як показав аналіз причин наднормативного простою вагонів на шляхах незагального користування, головною причиною їх виникнення $є$ неузгодженість дій 3 управління вагонопотоками на різних ділянках шляхів незагального користування та полігону примикання до мережі магістрального залізничного транспорту [6].

У суміжних технологічних ланках ще залишаються проблеми, рішення яких дозволило б додатково реалізувати резерви для організації більш погодженої роботи всіх учасників перевізного процесу:

1) технічний рівень ряду транспортних засобів і вантажно-розвантажувальних механізмів не цілком відповідає вимогам технології основного виробництва і взаємодії з залізничним транспортом загального користування;

2) єдині технологічні процеси роботи залізничної колії незагального користування i залізничної станції примикання (ЄТП), найчастіше, не націлені на оптимізацію використання технічних засобів взаємодіючих сторін. В даний час практичне значення СТП звелося до визначення терміну обороту вагонів на шляху незагального користування;

3) залишаються невирішеними до кінця питання організації процесу подачі і узгодження 
обсягів вантажів, що надаються до перевезення, 3 розподілом їх по напрямкам, покупцям і пунктам призначення;

4) відсутня державна та галузева політика в сфері промислового залізничного транспорту незагального користування і вантажовласників;

5) потенціал залізничного транспорту незагального користування (вагони) використовується недостатньо;

6) внаслідок необєктивної тарифної політики перевезення діляться на «вигідні» та «невигідні», що не сприяє нормальній роботі логістичної системи;

7) недостатньо стимулюється відправницька маршрутизація, відсутня чіткість у компенсації витрат на виконувані вантажовласниками початкові і кінцеві операції;

6) відсутне єдине інформаційне супроводження вантажів по всій території України різних видів транспорту, єдиний страховий простір $[6,13]$.

Аналіз проблеми ефективності функціонування й використання логістичних систем транспортних підприємств показав, що існуючі розробки як в організаційному плані, так і у плані оптимізації, розглядають, як правило, окремо або процес складування, накопичування, або процес транспортування, або процес обслуговування споживачів. Практично відсутні методи й моделі організації та управління вантажопотоками, що базуються на логістичних підходах та орієнтовані на безпосереднє використання споживачами чи постачальниками [13].

За думкою багатьох фахівців [2, 5, 9], саме відсутність логістичної інфраструктури є одним із стримуючих факторів забезпечення конкурентних переваг якості надання залізничних послуг та безперебійності функціонування ланцюга постачань. На стиках транспорту загального i незагального користування сьогодні з'являються об'єднання підприємств промислового транспорту по напрямках діяльності, що дозволить їм вийти на адміністративний рівень, а також формуються передумови для створення організацій, які зможуть запропонувати комплекс мультимодальних послуг і використовувати наскрізні тарифи.

Так, в даний час європейські логістичні транспортні схеми доповнюються потужними інформаційними центрами. Вони потім об'єднуються в розгалужену інтернаціональну інформаційну мережу. Це є основною причиною того, що всі закордонні інформаційні центри транспортної логістики мають державний статус. Іноді державі належить контрольний пакет акцій подібної структури [2].

Перспектива функціонування логістичного центру залізниці пов'язана 3 системним підходом до вирішення задач складання графіків доставки вантажів, маркетингу, прогнозування, виявлення «вузьких місць» на підставі аналізу потреб клієнтів та наявних можливостей залізниці, розробки методик та пропозицій розвитку (в чому числі 3 розвитку логістичної інфраструктури).

При впровадженні інформаційнологістичних центрів вирішуються такі аспекти: удосконалення системи документообігу на стику різніх відів транспорту; створення єдиної бази даних про всі етапи процесу перевезення вантажів.

Основним завданням інформаційнологістичних центрів $\epsilon$ створення єдиного інформаційного простору для учасників перевезень, что дозволить оптимізувати управління вантажопотоками, скоротити простої рухомого складу. Ця інформація повинна бути доступна всім учасникам транспортного процесу для оперативних виробок управлінських рішень, прогнозування та контролю над розвитком ситуації. Найбільший ефект інформаційнологістичні центри можуть забезпечити при розміщенні їх в районах концентрації підприємств машинобудування, хімічної, легкої та харчової промисловості, торгівлі, на стику залізничного та комунікацій автомобільного, морського, внутрішнього водного, повітряного транспорту [2].

При розробленні логістичної системи і їі структурної складової - системи зберігання й переробки продукції, - треба звернути увагу на моделювання оптимізації процесів, визначити пріоритетний критерій оптимальності. Таким комплексним критерієм виступає мінімум сукупних витрат, пов'язаних 3 утворенням i зберіганням вантажу на складах вантажовідправників або пунктах загального користування i збитками, що виникають при наявності перебоїв у забезпеченні логістичної системи необхідними ресурсами або збоїв, що трапляються в роботи вантажоодержувачів [10].

Висновки i перспективи подалыших досліджень. В даний час існує цілий ряд проблем, як нормативно-правового, так організаційнотехнічного характеру, які перешкоджають ефективній експлуатації промислового залізничного транспорту та його чіткій взаємодії 3 магістральним. Вирішення цих проблем може бути здійснено тільки на основі логістичного підходу, комплексного застосування передового досвіду та сучасних наукових методів, із залученням широкого кола фахівців залізниць, промислових підприємств і наукових організацій транспортної галузі.

Впровадження логістичних інноваційних технологій, що забезпечують комплексне транспортне обслуговування, передбачається на основі створення інформаційно-логістичного центру 3 надання якісних залізничних послуг вантажовласникам в умовах зміни кон'юнктури ринку. Функціонування інформаційнологістичного центру дозволить забезпечити координацію та інтеграцію учасників процесу 
перевезень, дотримання найважливіших критеріїв оптимальності, таких як якість, надійність та безпека процесу перевезень.

Подальшим напрямком досліджень $є$ визначення пріоритетних критеріїв оптимальності функціонування логістичної системи (якість транспортного обслуговування, стабільність та надійність надання послуги ті ін.).

\section{СПИСОК ЛІТЕРАТУРИ}

1 Вернигора, Р.В. Проблемы функционирования железнодорожных подъездных путей Украины в современных условиях [Текст] / P.В. Вернигора // Восточно-Европейский журнал передовых технологий. - 2012. - №58. - С.64-68.

2 Волкова, А.М. Взаимодействие ОАО «РЖД» и морских портов России на основе логистических принципов [Электронный ресурс] / A.M. Волкова. - Режим доступа www.sworld.com.ua/konfer27/625.pdf

3 Данько, M.I. Забезпечення конкурентоспроможності промислових підприємств в умовах міжнародних транспортних коридорів [Текст]: монографія / М.І. Данько, В.Л. Дикань, Н.В. Якименко. - Харків: УкрДАЗТ, 2008. $-170 \mathrm{c}$.

4 Дикань, В.Л. Ефективність роботи транспортної системи України в умовах глобалізації економічних систем [Текст] / В.Л. Дикань, М.В. Корінь //Вісник економіки транспорту i промисловості: збірник науковопрактичних статей. - Х.: УкрДАЗТ, 2011. - Вип. 33. - C. 13-19.

5 Дикань, В.Л. Основи логістичної інтеграції при формуванні логістичних систем через утворення територіально-промислового кластера [Текст] / В.Л. Дикань // Міжнародний техніко-економічний журнал «Українські залізниці», 2014. - № 9 (15). - С.23-26.

6 Дмитриев, А.В. Методологические основы управления логистикой транспортноскладских центров [Текст] / А.В. Дмитриев // Известия Санкт-Петербургского университета экономики и финансов. - 2012 . - Вып. №6. - С.7681.

7 Корпоративная логістика: 300 ответов на вопросы профессионалов [Текст] / под общ. и науч. редакцией В.И. Сергеева. - М.: ИНФРА-М, 2005. $976 \mathrm{c.}$
8 Миротин, Л.Б. Транспортная логистика: учебник для транспортных вузов [Текст] / Л.Б. Миротин. - М.: Экзамен, 2003. - 512 с.

9 Нестеренко, Г.І. Технологічні засади функціонування логістичного центру залізничного транспорту [Текст] / Г.I. Нестеренко, Г.I. Кириченко, О.О. Озерова // Вісник Східноукраїнського національного університету імені Володимира Даля - 2012. - №6 (177) - Ч.1 C.169-172.

10 Окороков, А.М. Підвищення ефективності логістичних систем шляхом обслуговування під'їних колій за твердими нитками графіку руху [Текст] / А.М. Окороков, Г.А. Подковирова // Перспективы взаимодействия железных дороги промышленных предприятий: Тезисы 2-й Международной научно-практической конференции (Кострина, 21-23 февраля 2013 г.) Д.: ДНУЖТ, 2013. - С.76-77.

11 Основы взаимодействия железных дорог с другими видами транспорта [Текст] /В.В. Повороженко, Н.К. Сологуб, А.А. Тимошин, В.Г.Галабурда; Под ред. В.В. Повороженко. -М.: Транспорт, 1986. - 215 с.

12 Пулатова, И. Р. Региональные проблемы формирования транспортнологистической системы (на материалах Согдийской области) [Электронный ресурс] / Режим доступа: http://cyberleninka.ru/article/n/regionalnye-problemyformirovaniya-transportno-logisticheskoy-sistemy-namaterialah-sogdiyskoy-oblasti

13 Рахмангулов, А.Н. Методологические основы организации функционирования железнодорожных промышленных транспортнотехнологических систем [Текст] / Автореф. дисс... докт. техн. наук: 05.22.01. -М., 2013. - 48 с.

14 Сухорукова, Т.Г. Характеристика класифікаційних ознак транспортної логістики [Текст] / Т.Г. Сухорукова, І.Л. Назаренко // Вісник економіки транспорту і промисловості: збірник науково-практичних статей. - Х.: УкрДАЗТ, 2014. - Вип. 47. - С. 51-57.

15 Шмулевич, М. И. Взаимодействие транспортников и грузовладельцев в логистических системах [Текст] /М.И. Шмулевич, С.Ю. Елисеев // Железнодорожный транспорт. 2007. - №8 - C.57-63.

Рецензент д.е.н., професор УкрДУЗТ Компанієць В.В. Експерт редакційної колегії к.е.н., доцент УкрДУЗТ Токмакова І.В. 